\title{
HUBUNGAN PENDIDIK DAN TERDIDIK DALAM AL-QURAN
}

\author{
Nurul Fatihah \\ Alumni PAI FAI UCY \\ Difla Nadjih \\ Fakultas Agama Islam UCY \\ binti_nadjih@yahoo.co.id
}

\begin{abstract}
What the relationships is like between educator and learner have actually been given in the Qur'an. Hamka is basically not a specialist in the field of education, inspite of this, he has heartedly investigated the aforementioned relationships as revealed in his monumental book of commentary, Tafsir al-Azhar, especially in Surat al-Alaq Verse 1-5. The relationships is build-up based on a pattern of learner-centered education which is different from educator-centered education pattern. The former is characteristically modern and the latter pattern is traditional in orientation. As an oustanding public figure raised-up in a religious environtment and actively engaged in struggle with the modernists movement in Indonesia, it is only natural that Hamka emphasizes the learner-centered pattern of education which is widely seen as a modern educational trend.
\end{abstract}

Keywords: relationship, educator, learner, the Quran

\begin{abstract}
Abstrak: Bagaimana hubungan pendidik dan terdidik telah diberikan dalam al Quran. Hamka pada dasarnya bukanlah pakar spesialis dalam bidang pendidikan, namun ia telah menggalinya seperti yang terungkap dalam Kitab Tafsirnya yang monumental, khususnya di surat al-Alaq Ayat 1-5. Hubungan tersebut dilandasi dengan pendidikan learned-centered disebut modern yang berbeda dengan pola pendidikan educator-centered. Pola kedua berorientasi tradisional. Sebagai seorang yang dibesarkan dalam lingkungan agama dan aktif dan berjuang bersama gerakan modernis di Indonesia, adalah wajar apabila Hamka menekankan pola pendidikan yang bercorak Learner-Centered yang dipandang sebagai tren pendidikan modern tersebut.
\end{abstract}

Kata kunci: hubungan, pendidik, terdidik, al-Quran

\section{A. Pendahuluan}

Istilah pendidikan adalah suatu aktivitas social penting yang berfungsi untuk mentansformasikan keadaan suatu masyarakat menuju keadaan yang lebih baik. Keterkaitan pendidikan dengan keadaan sosial amatlah erat, sehingga pendidikan mungkin mengalami proses spealisasi 
dan institusional sesuai dengan kebutuhan masyarakat yang kompleks dan modern. Pendidikan Islam memfokuskan perubahan tingkah laku manusia yang konotasinya pada pendidikan etika. Di samping itu, pendidikan Islam juga menekankan aspek produktivitas dan kreatifitas manusia sehingga mereka bisa berperan serta berprofesi dalam kehidupan bermasyarakat. ${ }^{1}$

Pendidikan menjadi usaha secara sadar untuk menumbuhkan pemahaman terhadap nilai-nilai moral keagamaan, sehingga anak didik dapat bersikap dan berperilaku sesuai moralitasnya. ${ }^{2}$ Arifin, ilmu pendidikan Islam penting dipelajari oleh setiap muslim yang berkeinginan agar pendidikan yang diselenggarakannya dapat berjalan lancar dan mencapai tujuan yang ditargetkannya. Ilmu pendidikan Islam berfungsi dalam rangka pembuktian terhadap teori-teori kependidikan Islam, juga memberikan informasi tentang pelaksanaan pendidikan dan pengembangannya, serta menjadi pengoreksi terhadap penyelenggaraan pendidikan Islam. 3

Salah satu tokoh Islam yang menyoroti arti pendidikan Islam di Indonesia adalah Hamka. Mahmud memujinya dalam penjelasan tentang keterkaitan pendidikan dalam keluarga dan sekolah. pendidikan di sekolah tak bisa lepas dari pendidikan di rumah. Karena, menurutnya, mesti ada komunikasi antara sekolah dengan rumah, antara orangtua murid dengan guru. Secara konvensional, antara orangtua murid dengan guru saling bersilaturahim, sekaligus mendiskusikan tentang perkembangan anak didiknya. Dan masjid adalah sarana untuk pertemuan tersebut. Dengan adanya shalat berjamaah di masjid, antara guru, orangtua, dan murid bisa saling berkomunikasi secara langsung. "Kalaulah

${ }_{1}$ Difla Nadjih dan Imroatun Imroatun, "Hadits Tentang Pendidikan Jasmani Anak Usia Dini," Prosiding Seminar Nasional Peran Pengasuhan Anak Raudhatul Atfal Dalam Membangun Karakter Bangsa, tahun 2016, h. 51-64; Imroatun Imroatun dan Difla Nadjih, "Anti-Violence Education in the Perspective of Hadith," Indonesian Journal of Islamic Early Childhood Education, IJIECE, Vol. 1, No. 1, December 2016 (121-130)

2 Joko Wahono, "Membangun Moralitas Dalam Hubungananak Dan Orang Tua," Academy Of Education Journal.Pendidikan Pancasila dan Kewarganegaraan Vol. 6 No. 2 Juli 2015, 23-34 Ke-1, h. 51 .

3 Mahmud, Pemikiran Pendidikan Islam, (Bandung: Cv Pustaka Setia, 2011), Cet. 
rumahnya berjauhan, akan bertemu pada hari Jum'at," begitu tutur Hamka. Relasi demikian bisa berjalan secara efektif di daerah-daerah pedesaan dimana mobilitas warganya belum begitu tinggi, sedangkan di perkotaan mobilitas yang tinggi juga jarak yang jauh. Di era modern ini, tetap ada sekolah-sekolah yang tetap menjaga semagat keumatan yang digagas oleh Hamka tersebut. Dengan menggunakan teknologi komunikasi yang berupa telpon dan internet, komunikasi orangtua dan murid akan terwujud dengan baik. 4

Pemikiran Pendidikan Hamka lainnya adalah hubungan antara pendidik dan terdidik yang terungkap dalam kitab tafsirnya. Hamka pada dasarnya bukanlah pakar spesialis dalam bidang pendidikan, namun pemikirannya tentang konsep pendidikan Islam pada umumnya dan kepribadian pendidik khususnya terungkap di dalamnya khususnya surat al-Alaq Ayat 1-5.

\section{A. Pendidik Ideal}

Budiutomo melalui Imron mengemukakan bahwa peningkatan kualitas komponen-komponen sistem pendidikan yang terbukti lebih berpengaruh terhadap peningkatan mutu pendidikan adalah komponen yang bersifat human resources. 5 Salah satunya adalah pendidik. Pengertian pendidik yang dikemukakan seperti diatas adalah pendidik dalam makna yang luas, baik dalam konteks pendidikan formal maupun pendidikan di luar sekolah. Ketika membahas pendidikan, Hamka mengacu pada pengertian pendidikan dalam cakupannya yang luas tersebut sebagaimana terkesan dari uraiannya ketika menjelaskan pengalaman belajarnya.

Sebagai pemegang peranan sentral dalam proses interaksi edukatif, tentu saja pendidik harus memiliki sifat sebagai guru. Masalahnya adalah bagaimana tipe pendidik yang ideal menurut konsepsi Hamka. Untuk menjawab hal ini, maka perlu ditelusuri pandangan Hamka tentang kepribadian yang harus dimiliki oleh pendidik dan sikap yang harus

5 Triwahyu Budiutomo, "Peningkatan Mutu Pendidikan Melalui Penilaian Proses Belajar Mengajar," Academy Of Education Journal. Pendidikan Pancasila dan Kewarganegaraan Vol. 6 No. 1 Januari 2015, 52-64 
dikembangkan pendidik dalam hubungan interaksi edukatifnya dengan peserta didik (anak didik).

Di dalam Al-Qur'an, hakikat guru adalah Allah, namun tidak berarti bahwa manusia tidak mempunyai tugas di dunia ini. Tugas manusia sebagai wakil-Nya (khalifah) di muka bumi ini. hubungan kodrati ini akan timbul pula hubungan antara yang lahir dengan yang dilahirkan. ${ }^{6}$ salah satu tugasnya adalah mengajarkan ilmu yang telah diperoleh kepada orang lain, dengan kata lain sebagai guru.

Melalui penjelasan pemikiran Al-Ghazali hakikat guru sebagai murabbi terungkap. Ditinjau dari segi misinya, yakni mengajak ke jalan Allah dengan mengajarkan ilmu pengetahuan serta menjelaskan kebenaran kepada manusia maka kedudukan guru sejajar dengan Nabi. Guru yang sempurna akalnya dan terpuji akhlaknya layak diberi amanah untuk mengajar peserta didik atau anak-anak pada umunya. 7

Pandangan Hamka tentang kepribadian pendidik pada dasarnya tidak banyak berbeda dengan pandangan Gazali yang dikemukakan terdahulu. Namun ada corak khas yang menonjol dari pandangannya, yaitu refleksi faham mistis atau tasawufnya. Hamka berpendapat bahwa seorang pendidik harus memiliki kepribadian yang progresif dalam ilmu pengetahuan dan mempunyai hubungan yang luas serta harmonis dengan orangtua atau wali murid, dengan sesama tenaga pendidik dan masyarakat luas. Hamka mengemukakan, Guru mendapat kemajuan dalam pekerjaannya dan menjadi penolong muridnya dalam mencapai kemajuan, ialah guru yang tidak hanya mencukupkan kepandaian yang dibawanya dari seorang guru saja, tetapi diperluas pengalaman dan pembacaan. Senantiasa tegas hubungannya dengan kemajuan modern dan luas pergaulannya, baik dengan wali murid atau sesama guru, sehingga bisa tambah menambah ilmu tentang soal pendidikan. Rapat hubungannya dengan orang-orang tua dan golongan muda supaya dia sanggup

6 Wahono, "Membangun Moralitas Dalam Hubungan anak Dan Orang Tua,"

7 Mahmud, Pemikiran Pendidikan Islam, (Bandung: CV Pustaka Setia, 2011), Cet. Ke-1, h. 247-249. 
mempertalikan dengan zaman baru dan dapat disisihkan mana yang yang antah dan mana yang beras. ${ }^{8}$

Hamka juga menekankan bahwa seorang pendidik harus memiliki jiwa dan kepribadian yang demokratis. Hal ini nampak jelas dari kritikannya yang keras terhadap cara pengajaran dan pendidikan yang dilakukan ayahnya terhadap dirinya yang dipandang bersikap "diktator". "kalau sekiranya cara mendidik beliau itu sejalan" tulis Hamka dalam ketidak setujuannya terhadap sikap pendidikan ayahnya, "maulah saya terbuang menjadi anak yang tidak berguna”. ${ }^{9}$

Di samping itu, Hamka juga mempersyaratkan seorang guru yang banyak pengalaman, luas pengetahuan, bijaksana dan pemaaf, tenang dalam memberi pengajaran, tidak lekas bosan lantaran itu tidak lekas dimengerti oleh murid agar menuntut ilmu dengan cara yang terbaik. ${ }^{10}$

Dalam konteks yang lebih luas, Hamka menekankan bahwa setiap muslim yang ingin mencapai kesempurnaan hidup yang hakiki menumbuhkan watak dan kepribadian yang sederhana, berani, percaya kepada diri sendiri, adil, bersahabat. Ikhlas, sabar, qana'ah, tawakal dan rendah hati. ${ }^{11}$

Ciri-ciri kepribadian yang sebagaimana dikemukakan sebelumnya, tentu saja harus pula dimiliki oleh setiap pendidik. Sebab sebagai figur keteladanan dan tokoh panutan bagi peserta didiknya bahkan bagi masyarakat pendidik harus memiliki semua ciri kepribadian mulia yang mungkin dicapai dan dimiliki oleh manusia. Dengan demikian, dapat disimpulkan bahwa tipe pendidik yang ideal menurut Hamka adalah harus memiiliki ciri-ciri kepribadian sebagai berikut:

a) Berpandangan maju dan progresif dalam mengikuti perkembangan ilmu pengetahuan dan teknologi.

b) Suka membangun hubungan yang luas dengan para orangtua dan wali murid serta seluruh lapisan anggota masyarakat.

c) Mempunyai hubungan yang harmonis dengan sesama pendidik.

8 Hamka, Lembaga Budi, (Jakarta: Pustaka Panjimas, 1983), h. 74.

9 Hamka, Falsafah Hidup, (Jakarta: Pustaka Panjimas, 1994), h. 2.

${ }^{10}$ Hamka, Lembaga Budi, h. 241.

${ }^{11}$ Hamka, Falsafah Hidup, h. 201-26o. 
d) Berwatak demokratis, dalam arti terbuka menerima realitas perbedaan pendapat dalam berbagai persoalan.

e) Memiliki komitmen beragama yang mendalam sebagai refleksi terhadap rasa cinta kepada Allah Subhanallahu wa Ta'ala.

f) Penampilan pribadi yang sederhana, berani, percaya pada diri sendiri, adil, bersahabat, ikhlas, sabar, qona'ah tawakkal, dan rendah hati.

Kompetensi Pendidik

Dalam pendangan Hamka, "inti pendidikan ialah membukakan mata orang agar penglihatannya itu luas dan jelas". ${ }^{12}$ Empat kompetensi guru kemudian menjadi bersifat holistik dan integratif dalam kinerjanya. Oleh karena itu, tugas guru meliputi; pengenalan peserta didik secara mendalam, penguasaan bidang studi baik disiplin ilmu maupun bahan ajar dalam kurikulum sekolah, penyelenggaraan pembelajaran yang mendidik yang meliputi perencanaan dan pelaksanaan pembelajaran, evaluasi proses dan hasil belajar serta tindak lanjut untuk perbaikan dan pengayaan dan pengembangan kepribadian dan profesionalitas secara berkelanjutan. ${ }^{13}$

Hamka mengembangkan kompetensi pendidikan dalam konsepsi pendidikannya. Menurut Hamka setiap pendidik dalam melaksanakan tugasnya harus memiliki kecakapan-kecakapan sebagai berikut:

a) Pendidik harus memahami dengan baik bakat dan minat peserta didik. Pandangan ini dikemukakan Hamka dengan ungkapan sebagai berikut: Tabiat, masa depan, dna jalan kehidupan manusia itu berbeda satu sama lain. Hendaklah pendidikan itu berikhtiar mengembangkan bakat, bukan membenamkannya.pendidikan yand didasarkan pada kepada paksaan, paling banyak menimbulkan jemu di dalam hati dan menghabiskan umur. ${ }^{14}$

b) Pendidik harus memahami dan menguasai metode pendidikan dalam pelaksanaan tugasnya.

12 Hamka, Lembaga Budi, h. 89.

13 Alim, Tafsir Pendidikan, h. 128-135.

14 Hamka, Lembaga Budi, h. 202. 
c) Pendidik harus mepunyai kecakapan dalam memberikan bimbingan kepada peserta didik.

Hamka menjelaskan kedua prinsip kompetensi itu dalam ungkapan yang berbeda. Banyak guru-guru agama yang gagal, mengeluh karena kegagalannya. Pelajaran yang diterima orang. Salah satu dari sebabnya ialah dia mendahulukan nadzi daripada basyir; mendahulukan ancaman dari bujukan. Dia mendahulukan 'usran daripada yusran, mendahulukan sukar daripada yang mudah. Dia mengusir bukan mengumpul. Kadang-kadang dia hendak membuat agama menurut kehendaknya bukan kehendak menurut Tuhan. Dan setelah dia gagal, dia menyalahkan orang lain. ${ }^{15}$

d) Pendidik harus memahami dengan tepat tujuan pendidikan dalam konteks zamannya dan dalam konteks antisipasi masa depan. Pada karya Hamka diungkapkan bahwa Kejayaan atau kegagalan hidup yang akan ditempuh oleh seorang anak sejak kecil sampai besar, sampai tua dan semua ditentukan di waktu membetuk dan melatihnya sejak kecil. Diwaktu yang lampaulah ditentukan jaman yang akan datanglah bergantung segala angan-angan kita dan cita-cita kita. Seorang anak yang masih kecil, walaupun setiap saat kita ingatkan supaya dia insa ke zaman yang akan datang, tidaklah mengerti bagaimana mahalnya. Yang mesti mengerti ialah pendidikannya, ayahnya, bundanya dan guru-gurunya.

e) Pendidik harus menguasai dengan baik materi pendidikan yang akan disampaikannya. Kalau seseorang hendak memberi penerangan kemuka umum hendaklah diketahuinya dan dikuasainya benar soal yang akan dibicarakan, apalah lagi mengenai ayat Tuhan dan Hadits Nabi. Kalau bacaannya salah, tidaklah dapat dihabiskan dengan maaf saja. ${ }^{16}$

1. Sikap Pendidik dalam Interaksi Pembelajaran

Tidak ada kesangsian bahwa sikap kecenderungan pendidik dalam hubungan interaksi pembelajaran dengan peserta didik (anak didik) 
mempunyai pengaruh yang cukup penting dalam menunjang keberhasilan pelaksanaan pendidikan. Hal ini disebabkan oleh kenyataan bahwa "apabila seorang guru mendapat kepercayaan dan kehormatan mengajar, kepadanya juga dipercayakan untuk mengambil keputusan yang bersifat normatif. ${ }^{17}$ Dengan kata lain keputusan normatif yang diambil pendidik dalam pelaksanaan tugasnya akan mempengaruhi sikap kecenderungan dan kebijakannya dalam hubungan interaksi pembelajaran dengan peserta didik yang pada gilirannya mempengaruhi proses dan keberhasilan pelaksanaan pendidikan yang baik. Sehingga perlu adanya patokanpatokan normatif tentang sikap, kecenderungan dan kebijakan yang perlu di kembangkan pendidik dalam hubungan interaksi pembelajarannya dengan pendidik, Hamka menulis:

Maka hendaklah guru itu menjadi contoh yang baik bagi muridnya, perangainya patut ditiru, menjadi ayah bersama, menjadi sahabat tempat menumpahkan perasaan hati dan mengadu di waktu pikiran tertumbuk. Bergaul dengan murid-murid itu dengan lemah lembut, tetapi tidak bersudut, keras tetapi di dalam kerasnya itu si murid merasa sendiri, bahwa pada waktu itu memang sudah seadilnya jika gurunya keras kepadanya. Kekerasan sekali-kali, samalah artinya dengan garam penambah enaknya sambal. ${ }^{18}$

\section{B. Perkembangan Kepribadian Peserta Didik dalam Proses Pendidikan}

Peserta didik juga termasuk faktor yang sama penting dalam pendidikan. Mereka bukan sekedar obyek, melainkan juga subyek pendidikan. Dalam pengertian sempit dari Marimba, peserta didik adalah orang-orang yang belum dewasa atau anak-anak yang masih memerlukan bimbingan orang dewasa. ${ }^{19}$ Pengertian luas yang disebut terakhir sesuai dengan prinsip long life education. Akan tetapi dalam sejumlah kesempatan Hamka cenderung mengacu kepada makna sempit ketika ia membicarakan peserta didik. Pandangan Hamka terhadap faktor yang

17 Winarno Surakhmad, Metodologi Pengajaran Nasional, (Bandung: Jammars,1979), h. 47-48.

${ }^{18}$ Hamka, Lembaga Budi, $h .75$.

19 Marimba, Pengantar Filsafat, h. 31-33. 
mempengaruhi perkembangan kepribadian peserta didik dan implikasi pandangannya dimaksud terhadap posisi dan peran peserta didik dalam proses kegiatan pendidikan.

Secara tidak langsung Hamka menolak aliran nativisme maupun empirisme dan lebih cenderung menerima pandangan konvergensi. Hal ini nampak jelas dari kritik yang dilontarkannya terhadap dua cara pendidikan yang berkembang dalam masyarakat. Cara yang pertama, anak didik tumbuh menurut garis yang dikehendaki orang tua; cara kedua anak-anak dibiarkan menurut bakatnya. Hamka menggambarkan cara yang pertama sebagai model pendidikan dimana peserta didik tidak memiliki kebebasan bergerak manurut gerak hatinya. Pada akhirnya yang terjadi adalah “... serba salah bagi nasib anak. Dia akan gagal sampai kepada tujuan hidupnya yang telah ada persediaan padanya tatkala dia dilahirkan yang dinamai bakat. ${ }^{20}$ Lebih jelas Hamka menjelaskan:

Kata mereka, begitulah pendidikan yang betul. Padahal itu satu penyakit yang tidak membiarkan manusia maju menurut bakat yang telah ditentukan Tuhan sejak dalam rahim. Mereka hendak membuat manusia menjadi satu corak saja serupa binatang dan tumbuh-tumbuhan. Padahal manusia bukan jenis kuda yang berguna di kendarai dan pengangkat barang. Manusia bukan sayur bayam tetapi sayur saja. Meraut dan membentuk anak menurut kehendak orangtua saja pada hakikatnya berbahaya pada anak itu, melamban kemajuannya. ${ }^{21}$

Kritik Hamka yang nampak sangat keras terhadap model atau cara pendidikan pertama tersebut dapat pula dipandang sebagai ketidaksetujuan terhadap faham empirisme yang sama sekali peranan individu umumnya dan dalam pendidikan khususnya. Akan tetapi, dalam hal lain Hamka juga tidak sepihak yang menganggap kepribadian individu hanya dibentuk oleh bakat yang dibawa sejak lahir danmerupakan peranan faktor lingkungan. Implikasi dari faham nativisme tersebut terhadap teori pendidikan ialah bahwa setiap individu harus diberikan kebebasan-kebebasan secara mutlak untuk mengaktualisasikan dirinya

20 Hamka, Falsafah Hidup, h. 201.

21 Ibid., h. 201-202. 
menurut bakatnya masing-masing. Ketidak kesepakatan Hamka dengan pandangan faham nativisme terungkap ketika ia mengatakan:

Pendidikan jenis kedua, adapula bahayanya kalau anak-anak dibiarkan menurut maunya, tidak dituntun. Cara demikian mencelakakan anak itu sendiri. Meskipun tadi dikatakan tiap-tiap manusia mempunyai bakat sendiri-sendiri, kalau ia masih anak-anak belumlah tentu apa bakat itu. Anak yang dididik demikan menjadi manja. ${ }^{22}$

Pandangan Hamka tentang perkembangan kepribadian peserta didik dalam proses pendidikan tersebut di atas pada dasarnya sesuai dengan persepektif ajaran Islam. Dalam sebuah Hadits, Nabi Shallalahu 'alaihi wassalam bersabda:

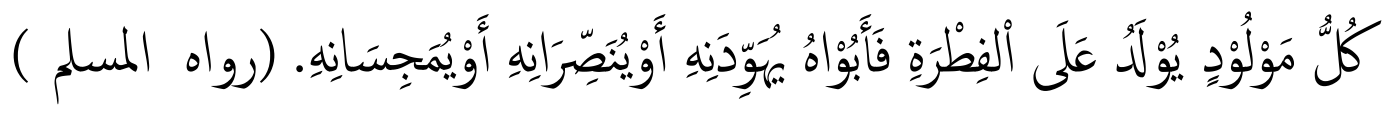

Menurut sementara pakar pendidikan Islam, istilah Fitrah yang dimaksud dalam Hadits tersebut adalah kecenderungan untuk beraqidah tauhid. Atau kecenderungan manusia menerima Allah SWT sebagai Tuhan atau kecenderungan alami pada manusia untuk berbakti dan menyembah Allah Subhanallahu wa Ta'ala". Kecenderungan tersebut menurut doktrin Al-Qur'an, merupakan pembawaan sejak lahir bahkan sudah tertanam sejak pre-natal. Hal ini dinyatakan oleh Al-Qur'an dengan ungkapan sebagai berikut:

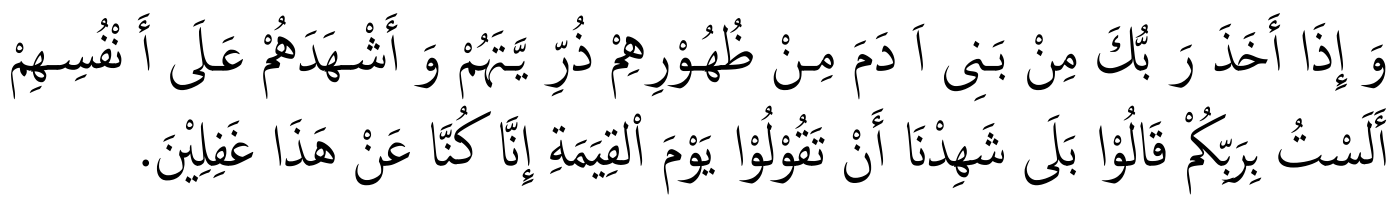

Dan (ingatlah), tatkala Tuhan engkau mengambil dari anak cucu Adam dari tulang-tulang punggung mereka, dan Dia jadikan saksi atas diri mereka sendiri." Bukankah Aku Tuhan kamu?" semua menjawab: "memang kami menyaksikan". (Q.S. Al-A'raf [7] : 172)23

Pada ayat lain Al-Qur'an menjelaskan sifat fitrah yang tertanam dalam batin atau nurani manusia dengan pernyataan sebagai berikut:

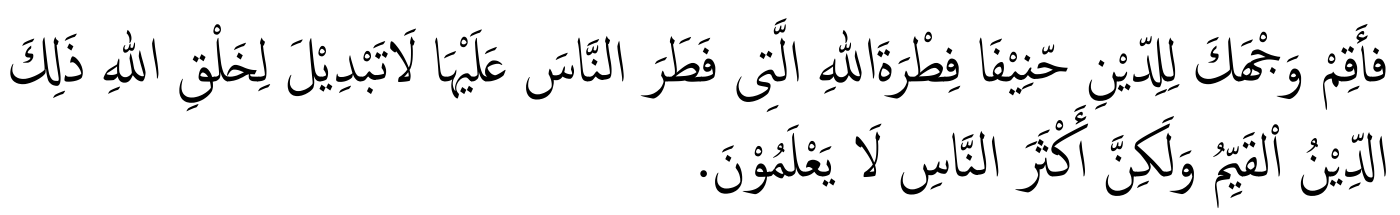

22 Ibid, h. 202.

23 Hamka, Tafsir Al-Azhar, (Jakarta: Pustaka Panjimas,1982), h. 155. 
Maka tegakkanlah wajah engkau kepada agama dalam keadaan lurus. Fitrah yang telah Dia fitrahkan manusia atasnya. Sekali-kali tidaklah ada pergantian pada ciptaan Allah Subhanallahu wa Ta'ala, itulah agama yang lurus. Tetapi teramat banyaklah manusia yang tidak mengetahuinya. (Q.S. Ar-Rum [3O]: 3O).24

Mengomentari ayat-ayat yang dikutip pertama, Hamka antara lain menyatakan secara berbeda. Maksud ayat itu adalah jiwa murni tiap-tiap manusia adalah dalam keadaan fitrah, masih bersih, belum ada pengaruh apa-apa. Pada jiwa yang masih murni itu sejak semula telah terdapat pengakuan bahwasanya pastilah ada pencipta dari seluruh alam ini. Tidaklah alam terjadi sendirinya dan tidak ada pula pencipta yang lain. Pencipta itu hanya Satu, Esa, Tunggal. Lebih jauh ditegaskan bahwa ayat itu juga “ menunjukkan bahwasanya jiwa seluruh manusia itu pada asalnya dan pokoknya adalah satu corak, semuanya sama-sama mengaku ada Tuhan Pencipta alam " 25.

Dengan demikian,”...boleh dikatakan bahwa adanya agama karena adanya fitrah manusia ", yakni kecenderungan untuk berakidah tauhid. Ayat 172 surat Al-A'raf itu, menurut Hamka esensinya berhubungan sangat erat dengan ayat 30 surat Ar-Rum yang dikutip kedua; demikian pula sebaliknya. Dalam keterkaitannya dengan ayat 172 surat Al-A'raf, maka ayat 30 surat Ar-Rum dimaksud bermakna : lazimillah atau tetaplah pelihara itrahmu sendiri yang belum kemasukan pengaruh dari yang lain, yaitu mengakui adanya kekuasaan tertinggi dalam alam ini. Interpretasi Hamka terhadap surat Ar-Rum yang dikemukakan terakhir dia atas secara implisit menekankan peranan pendidikan dalam rangka memelihara kemurnian fitrah asli agar tidak mengalami distorsi (penyimpangan) dalam perkembangannya. Walaupun tetap diyakini bahwa pada lubuk hati yang terdalam wujud fitrah itu tidak pernah berubah buat selamalamanya. Dalam konteks ini, adalah benar bila dikatakan bahwa gambaran Al-Qur'an mengenai tidak adanya perubahan pada fitrah yang tertanam di lubuk batin manusia itu tidaklah bertentangan dengan inti ajaran Hadits yang dikutip di awal yang menyatakan secara eksplisit bahwa faktor 
lingkungan dapat menyimpangkan arah perkembangan fitrah anak. Sebab yang dimaksud oleh Al-Qur'an pada surat Ar-Rum ayat 30 di atas ihwal tidak adanya perubahan atas fitrah atau kecendrungan dasar untuk beraqidah tauhid dalam diri manusia adalah yang sifatnya potensial. Fitrah potensial, bila tidak dipelihara dan ditumbuh kembangkan dalam cara yang tepat dan benar, maka akan selamanya hanya sebagai wujud bakat potensial. Sedangkat yang aktual membentuk watak kepribadian individu justru kecendrungan-kecendrungan "perolehan" yang belum tentu sesuai atau bertentangan dengan wujud fitrah potensial. ${ }^{26}$

Dalam ungkapan Hasan Langgulung, Islam itu adalah naluri asal manusia. Dengan kata lain, manusia itu bukanlah lahir dengan Islam tetapi ia memiliki potensi untuk menjadi Islam. Jadi sebab-sebab yang menjadikan orang-orang tidak percaya kepada Tuhan bukanlah sifat dari asalnya, tetapi ada kaitannya pada alam sekitarnya.

Berikanlah pada anak-anak kebebasan berpikir dan tuntunlah dia ini dalam kebebasan. Jangan dipaksakan anakanak menerima pelajaran yang tidak sesuai dengan bakatnya, baik oleh gurunya atau ayah bundanya atau oleh yang berkuasa. Supaya dia tidak seperti kayu yang layu pucuknya, karena tengah hari tetap siiram juga. Pendidikan yang bersifat pimpinan dan bersifat membuka jalan, adalah seumpama udara dan cahaya matahari supaya dia sanggup hidup sendiri. ${ }^{27}$

\section{Kesimpulan}

Dari uraian di atas cukup beralasan untuk menyatakan bahwa pandangan Hamka tentang perkembangan kepribadian peserta didik dalam proses pendidikan adalah buah dari refleksi atau renungan filosofis pedagogis yang bertolak dari doktrin Al-Qur'an dan As-Sunnah. Bahkan benar pula bila dikatakan seluruh pandangan tentang sistem pendidikan bertolak dari dan mendapatkan landasannya yang kokoh pada doktrin AlQur'an dan As-Sunnah.

Implikasi dari pandangan Hamka tentang perkembangan kepribadian peserta didik dalam proses pembelajaran yang dipaparkan di

${ }^{26}$ Ibid, (XXI), h. 78-79.

27 Hamka, Falsafah Hidup, h.204. 
awal, pada tingkat praktis ialah tuntutan bagi diterapkannya pola pendidikan atau pengajaran yang orientasinya berpusat pada peserta didik (learner centered orientation), bukan yang orientasinya berpusat pada pendidik (educator centered orientation). Ciri dan pola pendidikan yang bercorak learner-centered ialah peranan pendidik hanya minimal, pendidik lebih sebagai "pembimbing dan fasilisator" dengan keyakinan bahwa setiap siswa adalah manusia memiliki kemampuan-kemampuan yang wajar dan dapat mengatasi masalah-masalah yang dihadapinya. ${ }^{28}$

\section{Daftar Pustaka}

Alim, Akhmad. Tafsir Pendidikan Islam. Jakarta: AMP Press, 2014.

Badiatul Roziqin, dkk. 101 Jejak Tokoh Islam Indonesia. Yogyakarta: eNusantara, 2009.

Barnadib, Imam. Falsafah Pendidikan: Sistem dan Metode. Yogyakarta: Andi Offset, 1994.

Budiutomo. Triwahyu. "Peningkatan Mutu Pendidikan Melalui Penilaian Proses Belajar Mengajar," Academy Of Education Journal. Pendidikan Pancasila dan Kewarganegaraan Vol. 6 No. 1 Januari 2015, 52-64

Daulay, Haidar Putra. Pendidikan Islam dalam Sistem Pendidikan Nasional di Indonesia. Jakarta: Kencana, 2014.

Nadjih, Difla dan Imroatun Imroatun "Hadits Tentang Pendidikan Jasmani Anak Usia Dini," Prosiding Seminar Nasional Peran Pengasuhan Anak Raudhatul Atfal Dalam Membangun Karakter Bangsa, tahun 2016, h. 51-64

Hamka. Falsafah Hidup. Jakarta: Pustaka Panjimas. 1994.

--------. Lembaga Budi. Jakarta: Republika Penerbit, 2015.

---------. Tafsir Al-Azhar Juzu XXX. Jakarta: Pustaka Panjimas. 1988.

Ilham, M. Arifin. Filsafat Pendidikan Islam. Jakarta: Bumi Askara,1994.

Imroatun, Imroatun dan Difla Nadjih, "Anti-Violence Education in the Perspective of Hadith," Indonesian Journal of Islamic Early Childhood Education, IJIECE, Vol. 1, No. 1, December 2016 (121130)

Izzan, Ahmad \& Saehudin. Tafsir Pendidikan Studi Ayat-ayat Berdimensi Pendidikan. Banten: Pustaka Aulia Media (PAM Press), 2015.

Karim, M. Rusli. Pendidikan Islam di Indonesia Antara Cita dan Fakta. Yogyakarta: Tiara Wacana, 1991.

Kiraman, Muhammad. Konsep Pendidikan Islam menurut Haji Abdul Malik Karim Amrullah (HAMKA). Yogyakarta: Fakultas Agama Islam Universitas Cokroaminoto Yogyakarta. 2005.

Langgulung, Hasan. Manusia dan Pendidikan: Suatu Analisa Psikologi dan Pendidikan. Jakarta: Pustaka Al-Husna, 1989.

Mahmud. Pemikiran Pendidikan Islam. Bandung: CV Pustaka Setia, 2011.

${ }_{28}^{28}$ Imam Barnadib, Falsafah Pendidikan: Sistem dan Metode, (Yogyakarta: Andi Offset, 1994), h. 28. 
Marimba, Ahmad D. Pengantar Filsafat Pendidikan Islam. Bandung: AlMa'arif, 1901.

Nata, Abuddin. Metodologi Studi Islam. Jakarta: PT RajaGrafindo Persada, 2006.

Ngalim, Daru. Konsep Pendidikan Islam dalam Al-Qur'an Surat Al-'Alaq ayat 1 sampai dengan ayat 5. Yogyakarta: Fakultas Agama Islam Universitas Cokroaminoto Yogyakarta, 2009.

Pusat Bahasa Departemen Pendidikan Nasional. Kamus Besar Bahasa Indonesia Edisi Ketiga. Jakarta: Balai Pustaka, 2001.

Surakhmad, Winarno. Metodologi Pengajaran Nasional. Bandung: Jammars,. 1979.

Suryabrata, Sumadi. Psikologi Pendidikan. Jakarta: Rajawali Press, 1984.

Tafsir, Ahmad. Filsafat Pendidikan Islami. Bandung : PT Remaja Rosdakarya, 2014.

Wahono, Joko. "Membangun Moralitas Dalam Hubungan anak Dan Orang Tua," Academy Of Education Journal.Pendidikan Pancasila dan Kewarganegaraan Vol. 6 No. 2 Juli 2015, 23-34 